Jurnal Penelitian Perawat Profesional

Volume 3 Nomor 1, Februari 2021

e-ISSN 2715-6885; p-ISSN 2714-9757

http://jurnal.globalhealthsciencegroup.com/index.php/JPPP

\title{
EFEK ANTIDIABETIK DARI ALOE VERA
}

\author{
Cantika Larasati
}

Fakultas Kedokteran, Universitas Lampung, Jl. Prof. DR. Ir. Sumatri Brojonegoro No.1, Gedong Meneng, Kec. Rajabasa, Kota Bandarlampung, Lampung, Indonesia 35145 cantikalarasati12@gmail.com (+6281367108618)

\begin{abstract}
ABSTRAK
Diabetes melitus merupakan kelainan metabolisme kronis yang ditandai dengan hiperglikemia dengan gangguan metabolisme karbohidrat, lemak, dan protein. Pasien dengan diabetes mellitus seringkali memiliki kontrol glikemik yang buruk dan memiliki banyak risiko komplikasi mikrovaskuler. Obat hipoglikemik sintetik tidak dapat sepenuhnya mengontrol kadar glukosa serta seringkali menimbulkan efek samping yang menyebabkan ketidakpatuhan pasien minum obat. Selama berabad-abad, obat-obatan herbal telah banyak digunakan untuk mengobati berbagai macam penyakit yang sampai saat ini masih digunakan sebagai alternatif pertama untuk menyembuhkan penyakit tertentu di negara berkembang. Aloe vera telah digunakan oleh berbagai budaya karena khasiat obatnya yang luar biasa. Penelitian ini merupakan literature review yang melibatkan sebanyak 21 sumber pustaka dengan kata kunci yang digunakan yaitu 'aloe vera dan diabetes' dengan tahun terbit antara 2009- 2020. Abstrak dan full text jurnal dibaca dan dicermati, kemudian dilakukan analisis terhadap isi yang terdapat dalam tujuan penelitian dan hasil/temuan penelitian. Banyak studi menunjukkan ekstrak aloe vera dapat berperan dalam menurunkan glukosa darah pada penderita diabetes mellitus dan komplikasinya melalui berbagai mekanisme, seperti menurunkan glukoneogenesis dan lipogenesis, serta meningkatkan glikolisis di hati. Selain itu, aloe vera dapat mempengaruhi ekspresi gen berbeda yang terkait dengan metabolisme glukosa dan lipid. serta dikaitkan dengan aktivasi transkripsi PPAR. Kandungan senyawa dan vitamin didalamnya juga berperan sebagai antioksidan. Kandungan senyawa pada gel aloe vera menunjukkan berbagai manfaat antidiabetes, dan kandungan polisakarida di dalamnya dianggap sebagai komponen aktif utama untuk manfaat tersebut.
\end{abstract}

Kata kunci: aloe vera; diabetes mellitus

\section{ANTIDIABETIC EFFECTS OF ALOE VERA}

\section{ABSTRACT}

Diabetes mellitus is a chronic metabolic disorder characterized by hyperglycemia with disorders of carbohydrate, fat and protein metabolism. Patients with diabetes mellitus often have poor glycemic control and are at high risk of microvascular complications. Synthetic hypoglycemic drugs cannot completely control glucose levels and often cause side effects that cause patient non-adherence to take medication. Over the centuries, herbal medicines have been widely used to treat various diseases which are still used as the first alternative to cure certain diseases in developing countries. Aloe vera has been used by various cultures for its amazing medicinal properties. This research is a literature review involving 21 literature sources with the keywords used, namely 'aloe vera and diabetes' with the publication year between 2009 and 2020. Abstracts and full text journals are read and examined, then an analysis of the content contained in the research objectives is carried out. and research results/ findings. Many studies show aloe vera extract can play a role in lowering blood glucose in people with diabetes mellitus and its complications through various mechanisms, such as reducing gluconeogenesis and lipogenesis, and increasing glycolysis in the liver. In addition, aloe vera can influence the expression of different genes related to glucose and lipid 
metabolism. and was associated with PPAR transcription activation. The content of compounds and vitamins in it also acts as an antioxidant. The compound content in aloe vera gel shows various antidiabetic benefits, and the polysaccharide content in it is considered the main active component for these benefits.

Keywords: aloe vera, diabete mellitus

\section{PENDAHULUAN}

Diabetes mellitus adalah gangguan metabolisme yang mempengaruhi sekitar 285 juta orang dewasa di seluruh dunia. Diindikasikan bahwa angka ini akan meningkat dua kali lipat pada tahun 2030, yang akan setara dengan sebanyak $7,7 \%$ dari populasi dunia (Neumiller \& Umpierrez, 2018). Diabetes mellitus adalah disfungsi fisiologis yang ditandai dengan hiperglikemia akibat terhadap resistensi insulin, sekresi insulin yang tidak tepat dari pankreas atau ekskresi glukagon dalam jumlah besar. Jenis diabetes yang paling umum adalah diabetes mellitus tipe 2 (DMT2) yang berkembang dari kondisi pradiabetes. Pradiabetes digambarkan sebagai adanya kadar glukosa darah yang lebih tinggi dari kisaran normal, tetapi tidak cukup tinggi untuk dikategorikan sebagai diabetes. 4 DMT2 digambarkan sebagai adanya kadar glukosa darah yang tinggi akibat gangguan regulasi glukosa sebagai akibat tidak berfungsinya sel beta pankreas dan resistensi insulin. Manajemen diabetes yang buruk menyebabkan komplikasi jangka panjang yang mempengaruhi retina, ginjal dan sistem saraf. Dilaporkan bahwa diabetes adalah penyebab paling umum kebutaan, penyakit jantung dan amputasi pada penderitanya (Vitetta et al., 2020).

Penatalaksanaan diabetes melibatkan perawatan medis termasuk farmakoterapi atau obat anti-diabetes untuk pengelolaan DMT2 yang efektif. Terdapat berbagai jenis farmakoterapi yang tersedia untuk pengobatan diabetes antara lain biguanides, sulfonylureas, non-sulfonylureas, alpha glucosidase inhibitor, thiazolidinedione atau insulin sensitizer, intestinal lipase inhibitor, glukagon-like-peptide-1-reseptor

agonist, dipeptidyl-peptidase-4 inhibitor, sodium-glucose-cotransported type 2 (SGLT2) inhibitor dan terapi insulin. Namun, terapi konvensional modern ini juga memiliki banyak efek samping. Efek samping ini, dikombinasikan dengan kronisitas diabetes yang dapat menyebabkan kepatuhan yang buruk terhadap pengobatan farmakologis, sehingga pada gilirannya dapat menyebabkan gangguan kesehatan, dan akibatnya terjadi konsekuensi ekonomi yang signifikan. Modifikasi gaya hidup dalam hal olahraga teratur, pemeliharaan berat badan ideal, modifikasi diet dan swa-monitor kadar glukosa darah diketahui sebagai strategi efektif untuk manajemen diabetes. Terdapat tren yang muncul di seluruh dunia untuk penggunaan pengobatan tambahan dan alternatif, khususnya terapi berbasis biologis (suplemen makanan, herbal, produk nabati dan tumbuhan), khusunya produk nabati untuk memperbaiki kadar glukosa darah (Kaur et al., 2017).

Selama berabad-abad, obat-obatan herbal telah banyak digunakan untuk mengobati berbagai macam penyakit. Sampai saat ini, banyak dari tanaman ini masih digunakan sebagai alternatif pertama untuk menyembuhkan penyakit tertentu di negara berkembang di seluruh dunia karena efek sampingnya yang sedikit, juga dilaporkan bahwa 
sekitar $20 \%$ obat yang digunakan di seluruh dunia berasal dari tumbuhan (Muñiz-Ramirez et al., 2020). Sehingga semakin berkembang minat untuk menemukan sumber tanaman yang aman dan tidak beracun untuk mencari obat alternatif atau pelengkap yang membantu pengobatan berbagai penyakit kronis seperti diabetes melitus. Aloe vera telah digunakan oleh berbagai budaya seperti di Mesir, India, Cina, dan Eropa selama lebih dari 5000 tahun karena khasiat obatnya yang luar biasa (Benzidia et al., 2019).

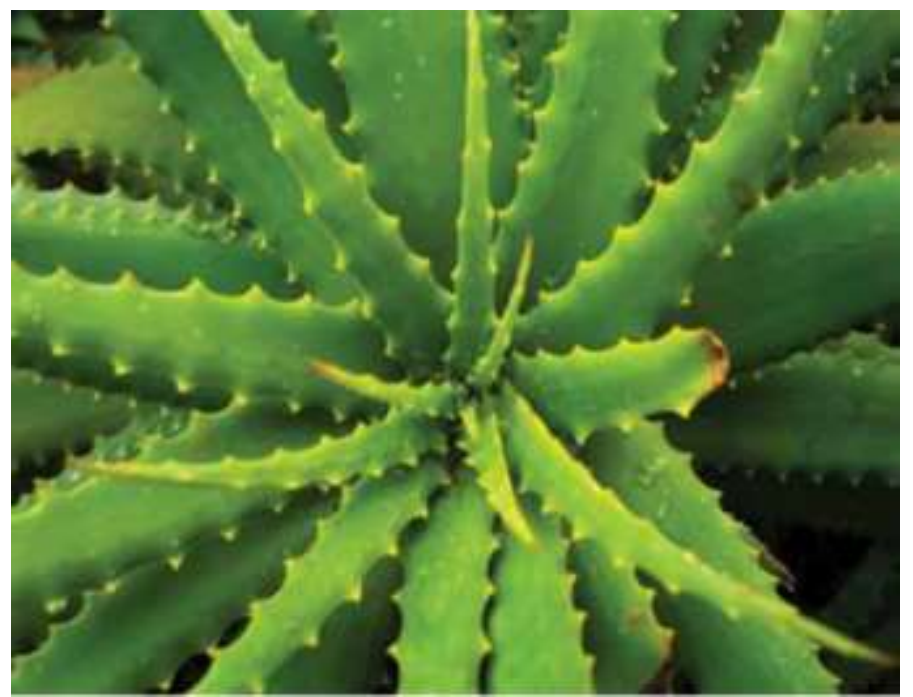

Gambar 1. Aloe vera (Aloe barbadensis) (Ngo et al., 2010)

Genus Aloe tumbuh di daerah kering, tropis, dan subtropis, yang genus ini mencakup sekitar 450 spesies. Aloe vera merupakan tanaman sukulen tanpa batang atau batang pendek dan dapat tumbuh setinggi 60-100 cm (MuñizRamirez et al., 2020). Setiap tanaman aloe vera biasanya memiliki rata-rata 12-16 daun. Daun aloe vera terbagi menjadi tiga bagian, yaitu lapisan tebal luar, lapisan tengah, dan gel bagian dalam. Lapisan kulit luar hijau, memiliki peran protektif terutama terlibat dalam produksi karbohidrat dan protein (Kar \& Bera, 2018). Lapisan tengah menghasilkan lateks kuning yang sangat pahit, biasa disebut jus lidah buaya, atau getah, atau gaharu yang kepahitannya disebabkan oleh adanya aloin, aloe emodin, dan senyawa terkait yang mengandung antrakuinon konsentrasi tinggi. Bagian daun ini juga memiliki unsur lain, termasuk barbaloin, aloe - emodin - 9 - anthrone, isobarbaloin, anthrone glycosides, dan chromones. Gel bagian dalam mengandung $98 \%$ air, bagian padat $0,66 \%$, dan padatan larut $0,56 \%$. (Shakib et al., 2019). Daunnya berdaging, tebal, berbentuk segitiga, dan berduri yang memberi kesan seperti kaktus, tetapi sebenarnya termasuk dalam famili lilac (Liliacea) (Benzidia et al., 2019). Daun aloe vera juga memiliki kemampuan untuk menahan air, yang memungkinkan tanaman untuk bertahan hidup di lingkungan dengan periode kekeringan yang lama (Maan et al., 2018). Aloe vera mengandung lebih dari 70 senyawa aktif (Muñiz-Ramirez et al., 2020). Bentuk kering aloevera gel mengandung polisakarida (53\%), gula $(17 \%)$, mineral $(16 \%)$, protein $(7 \%)$, lipid (5\%), dan senyawa fenolik (2\%). Selain itu, vitamin, mineral, lignin, saponin, asam salisilat, dan asam amino mempunyai aktivitas fungsional pada tumbuhan ini (Kar \& Bera, 2018). 
Berbagai studi menunjukkan bahwa polisakarida yang ada dalam gel aloe vera memiliki sifat terapeutik seperti anti-inflamasi, penyembuhan, sifat antibakteri, antioksidan, antikarsinogenik, antidiabetik, dan antipenuaan (Muñiz-Ramirez et al., 2020). Oleh karena itu, tujuan dari literature review ini adalah untuk mengetahui potensi aloevera sebagai antidiabetes, agar dapat memberikan informasi dan dimanfaatkan oleh masyarakat, terlebih tanaman ini banyak di temukan di Indonesia.

\section{METODE}

Penelitian ini merupakan studi literature review, yang menyajikan kembali materi yang diterbitkan sebelumnya, dan melaporkan fakta atau analisis baru. Penelusuran sumber pustaka dalam artikel ini melalui database PubMed dan Google Scholar. Sumber pustaka yang digunakan dalam penyusunan melibatkan 21 pustaka dengan kata kunci yang digunakan dalam penelusuran antara lain 'aloe vera dan diabetes' dengan tahun terbit antara 2009- 2020. Pemilihan artikel sumber pustaka dilakukan dengan melakukan peninjauan pada judul, abstrak dan hasil yang membahas manfaat antidiabetik dari tanaman aloevera. Abstrak dan full text jurnal dibaca dan dicermati, kemudian dilakukan analisis terhadap isi yang terdapat dalam tujuan penelitian dan hasil/temuan penelitian. Dilakukan koding terhadap isi jurnal yang direview berdasarkan garis besar atau inti dari penelitian tersebut yang dilakukan dengan mengurai dalam sebuah kalimat, dan jika sudah terkumpul kemudian dicari persamaan dan perbedaan pada masing-masing penelitian lalu dibahas untuk menarik kesimpulan. Hasil studi literatur ini berupa publikasi yang relevan.

\section{HASIL}

Huseini et al (2012) melakukan uji klinis pada pasien diabetes tipe 2 berusia 40 sampai 60 tahun dengan hiperlipidemia (hiperkolesterolemia dan / atau hipertrigliseridemia) yang tidak menggunakan agen anti-hiperlipidemik lain dan resisten terhadap asupan harian dua tablet glyburide $5 \mathrm{mg}$ dan dua tablet metformin $500 \mathrm{mg}$. Kemanjuran dan keamanan mengonsumsi lidah buaya gel (satu kapsul $300 \mathrm{mg}$ setiap 12 jam selama 2 bulan) dikombinasikan dengan obat yang disebutkan di atas dalam pengobatan 30 pasien dievaluasi dan dibandingkan dengan kelompok plasebo $(\mathrm{n}=30)$. Gel lidah buaya menurunkan kadar glukosa darah puasa, HbA1c, kolesterol total, dan LDL secara signifikan (masing-masing $\mathrm{p}=0,036, \mathrm{p}$ $=0,036, \mathrm{p}=0,006$, dan $\mathrm{p}=0,004$, ) tanpa efek signifikan pada kadar lemak darah dan hati lainnya. I tes fungsi ginjal ( $p>0,05)$ dibandingkan dengan plasebo. Tidak ditemukan efek samping dan hasil penelitian menunjukkan bahwa gel lidah buaya dapat menjadi anti-hiperglikemik dan antihiperkolesterolemia yang aman untuk pasien DMT2 hiperlipidemia (Huseini et al., 2012).

Penelitian lain juga dilakukan oleh Suksomboon et al (2016) dengan melibatkan 470 pasien (masing-masing 235 untuk pradiabetes dan diabetes tipe 2). Pada pradiabetes, Aloe vera secara signifikan memperbaiki gula darah puasa (GDP) (perbedaan rata-rata $-0,22$ mmol / L, 95\% CI -0,32 mmol / L menjadi $-0,12 \mathrm{mmol} / \mathrm{L}, \mathrm{p}<0,0001)$, tanpa efek pada HbA1c (perbedaan ratarata $-2 \mathrm{mmol} / \mathrm{mol}, 95 \% \mathrm{CI}-5 \mathrm{mmol} /$ mol sampai $-1 \mathrm{mmol} / \mathrm{mol})$. Aloe vera juga memperbaiki kontrol glikemik pada diabetes tipe 2, dengan sedikit perbaikan GDP (perbedaan rata-rata $1,17 \mathrm{mmol} / \mathrm{L}, 95 \% \mathrm{CI}-2,35 \mathrm{mmol} / \mathrm{L}$ 
menjadi $000 \mathrm{mmol} / \mathrm{L}, \mathrm{p}=0,05)$ dan perbaikan yang signifikan pada $\mathrm{HbA1c}$ (perbedaan rata-rata $-11 \mathrm{mmol} / \mathrm{mol}$, 95\% CI -19 mmol / mol menjadi -2 mmol / mol, $\mathrm{p}=0,01$ ) (Suksomboon et al., 2016)

Zhang et al (2016) juga melakukan uji coba terkontrol secara acak (RCT) yang melibatkan sebanyak 415 pesert. Dibandingkan dengan kelompok kontrol, suplementasi lidah buaya secara signifikan mengurangi kadar glukosa darah puasa (GDP) $(\mathrm{p}=0,02$; weighed mean difference (WMD) 30,05 mg / dL; 95\% CI -54,87 hingga $5,23 \mathrm{mg} \mathrm{/} \mathrm{dL}$ ), hemoglobin A1c terglikosilasi $\quad(\mathrm{HbA1c}) \quad(\mathrm{p}<0,00001$; WMD: $-0,41 \%$; $95 \%$ CI: $-0,55 \%$ hingga $-0,27 \%)$, trigliserida $(\mathrm{p}=0,0001)$, kolesterol total (TC) ( $\mathrm{p}<0,00001$ ), dan kolesterol lipoprotein densitas rendah (LDL-C) ( $\mathrm{p}<0,00001)$. Aloe vera lebih unggul dari plasebo dalam meningkatkan kadar kolesterol HDL serum $(p=0,04)$. Sehingga RCT ini menunjukkan bahwa lidah buaya dapat secara efektif mengurangi kadar GDP, HbA1c, trigliserida, TC dan LDL-C, dan meningkatkan kadar HDL-C pada pasien pradiabetes dan pasien diabetes yang tidak diobati (Zhang et al., 2016).

Sementara itu, Choi et al (2013) melihat pengaruh aloe vera gel complex (Aloe QDM complex) terhadap berat badan, massa lemak tubuh, glukosa darah puasa (GDP), insulin serum puasa, dan Homeostasis Model of Assessment Insulin Resistance (HOMA-IR) pada individu obesitas dengan pradiabetes atau DM dini yang tidak menjalani pengobatan diabetes. Sebanyak 136 peserta secara acak dibagi ke kelompok intervensi dan kelompok control, serta dievaluasi pada awal, minggu keempat dan minggu kedelapan. Selama 8 minggu, didapatkan bahwa berat badan $(\mathrm{p}=0,02)$ dan massa lemak tubuh $(\mathrm{p}=$ $0,03)$ secara signifikan lebih rendah pada kelompok intervensi. Pada 4 minggu, tingkat insulin serum $(\mathrm{p}=0,04)$ dan HOMA-IR $(\mathrm{p}=0,047)$ lebih rendah pada kelompok intervensi; hal ini juga lebih rendah pada 8 minggu tetapi tidak signifikan (masing-masing $\mathrm{p}=0,09$ dan 0,08). Pada 8 minggu, GDP cenderung menurun pada kelompok intervensi $(\mathrm{p}=$ $0,02)$, tetapi perbedaan antar kelompok tidak signifikan $(p=0,16)$. Sehingga disimpulkan bahwa individu obesitas dengan pradiabetes atau DM dini yang tidak diobati, Aloe QDM complex dapat menurunkan berat badan, massa lemak tubuh, dan resistensi insulin (Choi et al., 2013).

\section{PEMBAHASAN}

Baik kulit daun yang berwarna hijau dan jaringan parenkim putih / tidak berwarna bagian dalam (sumber gel) pada aloe vera mengandung daftar panjang senyawa bioaktif antara lain asam amino, peptida, protein / enzim, karbohidrat (mono-, di-, dan polisakarida unik), mineral dan vitamin, serta metabolit sekunder yang termasuk dalam kelas umum antrakuinon / antron, kromon, fitosterol, dan fenolat (Habtemariam, 2017). Berbagai senyawa ini telah menunjukkan beberapa tingkat aktivitas antidiabetes, tetapi polisakarida pada gel aloe telah sebagian besar dianggap sebagai komponen aktif utama untuk efek antidiabetes. Sementara antrakuinon / anthrones-nya dikaitkan dengan efek pencahar umum dari Aloe (Radha \& Laxmipriya, 2015)

Beberapa mekanisme mungkin terlibat dalam hubungan antara metabolisme glukosa-lipid dan lidah buaya. Bisa jadi karena khasiat polisakarida berat molekul tinggi atau fitosterol yang diisolasi dari gel lidah buaya 
meningkatkan transportasi glukosa dengan memodulasi penanda proksimal dan distal yang terlibat dalam pengambilan glukosa dan mengurangi konsentrasi serum kolesterol dengan mengurangi penyerapan kolesterol dari usus. Teori lain adalah bahwa ekstrak lidah buaya dapat menurunkan kadar glukosa darah dan lipid pada tikus diabetes dengan cara mengurangi efek toksik lemak di hati untuk meningkatkan sensitivitas sel terhadap insulin. Juga telah dihipotesiskan bahwa normalisasi status lipid plasma oleh lidah buaya dapat dijelaskan oleh kemampuannya untuk menekan ekspresi gen adipogenik, peningkatan pembersihan dan penurunan produksi transporter utama dari kolesterol dan trigliserida yang disintesis secara endogen (Zhang et al., 2016). Selain itu, beberapa peneliti percaya bahwa lidah buaya mengurangi lemak tubuh dan meningkatkan sensitivitas insulin dengan mengaktifkan protein kinase otot yang diaktifkan adenosin monofosfat, yang penting dalam regulasi metabolisme glukosa dan lipid (Shin et al., 2011).

Ketika kadar gula darah naik, penumpukan fruktosa di berbagai organ dapat terjadi. Baik fruktosa dan produk yang berasal dari oksidasi seperti metilglioksal dapat bereaksi dengan protein dan membentuk advanced glycation end products (AGEs). Arginin adalah salah satu target utama glikosilasi protein oleh karbonil reaktif, yang bereaksi dengan gugus guanidin dari arginin untuk membentuk AGEs. Oleh karena itu, menghambat glikasi protein dan produk pengoksidasi mereka sangat penting untuk mencegah komplikasi diabetes. Penelitian menunjukkan bahwa ekstrak aloe vera methanol (AVM) menunjukkan aktivitas penghambatan dalam pembentukan metilglioksal dan arginin, dan hal ini terjadi kemungkinan karena adanya flavonoid. Diketahui bahwa flavonoid, proanthocyanidins dan asam fenolat, dapat menghambat proses glikasi, karena mereka menghambat pembentukan AGEs dengan menangkap prekursor seperti 1,2dikarbonil atau berinteraksi dengan glukosa, mencegahnya bergabung dengan protein. Konsentrasi glukosa postprandial yang tinggi merupakan faktor risiko komplikasi mikrovaskuler dan makrovaskuler pada diabetes mellitus. AVM juga menunjukkan aktivitas penghambatan enzim $\alpha$ amilase dan $\alpha$-glukosidase karena flavonoid dalam aloe vera dapat menjadi penghambat enzim ini karena kemampuannya untuk mengikat protein (Muñiz-Ramirez et al., 2020). Studi yang dilakukan (Abo-Youssef \& Messiha (2013) tentang ekstrak lidah buaya menunjukkan bahwa lidah buaya dapat bertindak sebagai agen hipoglikemik melalui penghambatan aktivitas amilase pankreas yang kuat. tindakan ini menurunkan pemecahan pati dan menawarkan kontrol glikemik postprandial yang baik (Abo-Youssef \& Messiha, 2013). AVM juga diketahui menghambat lipase pankreas, dan diketahui bahwa sensitivitas insulin berhubungan dengan peningkatan lemak tubuh, sehingga menghambat lipase pankreas dapat menjadi cara untuk menghambat penyerapan lemak. Flavonoid mampu menghambat lipase pankreas karena senyawa ini dapat menonaktifkan lipase melalui pengikatan enzim yang tidak spesifik (Muñiz-Ramirez et al., 2020).

Karboksimetil lisin adalah salah satu AGEs dengan karakteristik terbaik secara kimiawi, yang telah digunakan sebagai penanda utama AGEs dalam banyak penelitian (Chen et al., 2019). 
Penelitian menunjukkan bahwa karboksimetil lisin dapat berinteraksi dengan Receptor for Advanced Glycation Endproducts (RAGE) dengan menonaktifkan jalur pensinyalan, yang mengarah pada ekspresi gen proinflamasi (Wautier et al., 2017). Karboksimetil lisin telah ditemukan di pembuluh darah retina pada penderita DMT2, dan dikaitkan dengan derajat retinopati dan sehingga penting untuk menemukan senyawa yang menghambat pembentukan karboksimetil lisin. AVM menunjukkan kemampuan untuk mengurangi pembentukan karboksimetil lisin secara signifikan, yang dapat menjadi alternatif untuk mengurangi komplikasi diabetes terkait AGEs (Muñiz-Ramirez et al., 2020)

Ekstrak aloe vera dapat berperan dalam menurunkan glukosa darah pada penderita diabetes mellitus dan komplikasinya melalui berbagai mekanisme, seperti menurunkan glukoneogenesis dan lipogenesis, serta meningkatkan glikolisis di hati. Selain itu, aloe vera dapat mempengaruhi ekspresi gen berbeda yang terkait dengan metabolisme glukosa dan lipid. aloe vera juga dikaitkan dengan aktivasi transkripsi PPAR. Menurut penelitian, lophenol dan cycloartenol, sebagai dua fitosterol, yang diisolasi dari gel aloe vera, menunjukkan peran penting dalam efek antidiabetes tanaman ini. Stres oksidatif dapat menjadi penyebab berbagai komplikasi diabetes melitus. Dalam hal ini, salah satu mekanisme antidiabetik terpenting aloe vera adalah fitur antioksidannya yang diamati pada berbagai senyawa tanaman ini (misalnya, fenol, flavonoid, dan vitamin C dan E). Selain itu, aloe vera telah terbukti memiliki efek antidiabetes pada subjek dengan kondisi hiperglikemik. Namun, dampak ini tidak terlihat pada kasus dengan kadar glukosa darah normal. Ini menunjukkan bahwa tanaman ini memiliki efek antihiperglikemik daripada aktivitas hipoglikemik. Hipoglikemia tetap merupakan efek samping utama dari agen antidiabetik; namun diketahui bahwa aloe vera tidak memberikan pengaruh pada glukosa darah normal (Shakib et al., 2019).

Sampai saat ini, belum ditemukan literatur mengenai efek toksik dari sediaan ekstrak aloe vera (Pothuraju et al., 2016). Pemberian ekstrak gel daun aloe vera secara oral (kapsul $600 \mathrm{mg} /$ hari) kepada pasien DMT2 selama 60 hari tidak memiliki efek buruk pada lipid peredaran darah dan tidak berpengaruh pada jaringan ginjal dan hati (Huseini et al., 2012). Demikian pula Yagi et al. (2009) melaporkan bahwa pemberian fraksi Aloe vera $L$. high molecular weight (AHM) yang mengandung barbaloin dan verektin pada pasien diabetes selama 12 minggu tidak menunjukkan efek samping dan bermanfaat untuk meredakan komplikasi pembuluh darah tepi dengan mengaktifkan sistem imun (Yagi et al., 2009).

\section{SIMPULAN}

Kandungan senyawa pada gel aloe vera menunjukkan berbagai manfaat antidiabetes, dan kandungan polisakarida di dalamnya dianggap sebagai komponen aktif utama untuk manfaat tersebut. Aloe vera berperan dalam menurunkan glukosa darah pada penderita diabetes mellitus dan komplikasinya melalui berbagai mekanisme, seperti menurunkan glukoneogenesis dan lipogenesis, serta meningkatkan glikolisis di hati. Selain itu, aloe vera dapat mempengaruhi ekspresi gen berbeda yang terkait dengan metabolisme glukosa dan lipid. serta dikaitkan dengan aktivasi 
transkripsi PPAR. Kandungan senyawa dan vitamin didalamnya juga berperan sebagai antioksidan.

\section{DAFTAR PUSTAKA}

Abo-Youssef, A. M. H., \& Messiha, B. A. S. (2013). Beneficial effects of Aloe vera in treatment of diabetes: Comparative in vivo and in vitro studies. Bulletin of Faculty of Pharmacy, Cairo University, 51(1), 7-11. https://doi.org/10.1016/j.bfopcu.2 012.03 .002

Benzidia, B., Barbouchi, M., Hammouch, H., Belahbib, N., Zouarhi, M., Erramli, H., Ait Daoud, N., Badrane, N., \& Hajjaji, N. (2019). Chemical composition and antioxidant activity of tannins extract from green rind of Aloe vera (L.) Burm. F. Journal of King Saud University - Science, 31(4), 11751181.

https://doi.org/10.1016/j.jksus.201 8.05 .022

Chen, Y., Tang, S., Chen, Y., Zhang, R., Zhou, M., Wang, C., Feng, N., \& Wu, Q. (2019). Structureactivity relationship of procyanidins on advanced glycation end products formation and corresponding mechanisms. Food Chemistry, 272, 679-687. https://doi.org/10.1016/j.foodche m.2018.08.090

Choi, H. C., Kim, S. J., Son, K. Y., Oh, B. J., \& Cho, B. L. (2013). Metabolic effects of aloe vera gel complex in obese prediabetes and early non-treated diabetic patients: Randomized controlled trial. Nutrition, 29(9), 1110-1114. https://doi.org/10.1016/j.nut.2013. 02.015
Habtemariam, S. (2017). Could we really use aloe vera food supplements to treat diabetes? Quality control issues. EvidenceBased Complementary and Alternative Medicine, 2017. https://doi.org/10.1155/2017/4856 412

Huseini, H. F., Kianbakht, S., Hajiaghaee, R., \& Dabaghian, F. H. (2012). Anti-hyperglycemic and anti-hypercholesterolemic effects of aloe vera leaf gel in hyperlipidemic type 2 diabetic patients: A randomized doubleblind placebo-controlled clinical trial. Planta Medica, 78(4), 311316. https://doi.org/10.1055/s0031-1280474

Kar, S. K., \& Bera, T. K. (2018). PHYTOCHEMICAL CONSTITUENTS OF ALOE VERA AND THEIR MULTIFUNCTIONAL PROPERTIES: COMPREHENSIVE REVIEW Sanjit Kumar Kar and Tushar Kanti Bera * Department of Physiology, Universal College of Medical Sciences, Bhairahawa, Lumbini Zone, Nepal. International Journal of Pharmaceutical Sciences and Research, 9(4), 1416-1423. https://doi.org/10.13040/IJPSR.09 75-8232.9(4).1416-23

Kaur, N., Fernandez, R., \& Sim, J. (2017). Effect of Aloe vera on glycemic outcomes in patients with diabetes mellitus: a systematic review protocol. JBI Database of Systematic Reviews and Implementation Reports, 15(9), 2300-2306. https://doi.org/10.11124/JBISRIR $-2016-002958$ 
Maan, A. A., Nazir, A., Khan, M. K. I., Ahmad, T., Zia, R., Murid, M., \& Abrar, M. (2018). The therapeutic properties and applications of Aloe vera: A review. Journal of Herbal Medicine, 12, 1-10. https://doi.org/10.1016/j.hermed.2 018.01 .002

Muñiz-Ramirez, A., Perez, R. M., Garcia, E., \& Garcia, F. E. (2020). Antidiabetic Activity of Aloe vera Leaves. Evidence-Based Complementary and Alternative Medicine, 2020. https://doi.org/10.1155/2020/6371 201

Neumiller, J. J., \& Umpierrez, G. E. (2018). 2018 standards of care update: Pharmacologic approaches to glycemic management in people with type 2 diabetes. Diabetes Spectrum, 31(3), 254-260. https://doi.org/10.2337/ds18-0030

Ngo, M. Q., Nguyen, N. N., \& Shah, S. A. (2010). Oral aloe vera for treatment of diabetes mellitus and dyslipidemia. Am J Health-Syst Pharm, 67, 1804-1811.

Pothuraju, R., Sharma, R. K., Onteru, S. K., Singh, S., \& Hussain, S. A. (2016). Hypoglycemic and Hypolipidemic Effects of Aloe vera Extract Preparations: A Review. Phytotherapy Research, 30(2), 200-207. https://doi.org/10.1002/ptr.5532

Radha, M. H., \& Laxmipriya, N. P. (2015). Evaluation of biological properties and clinical effectiveness of Aloe vera: A systematic review. Journal of Traditional and Complementary Medicine, 5(1), 21-26. https://doi.org/10.1016/j.jtcme.20

\subsubsection{6}

Shakib, Z., Shahraki, N., Razavi, B. M., \& Hosseinzadeh, H. (2019). Aloe vera as an herbal medicine in the treatment of metabolic syndrome: A review. Phytotherapy Research, 33(10), 2649-2660. https://doi.org/10.1002/ptr.6465

Shin, E., Shin, S., Kong, H., Lee, S., Do, S.-G., Jo, T. H., Park, Y.-I., Lee, C.-K., Hwang, I.-K., \& Kim, K. (2011). Dietary Aloe Reduces Adipogenesis via the Activation of AMPK and Suppresses Obesity-related Inflammation in Obese Mice. Immune Network, 11(2), 107. https://doi.org/10.4110/in.2011.11 .2 .107

Suksomboon, N., Poolsup, N., \& Punthanitisarn, S. (2016). Effect of Aloe vera on glycaemic control in prediabetes and type 2 diabetes: A systematic review and metaanalysis. Journal of Clinical Pharmacy and Therapeutics, 41(2), 180-188. https://doi.org/10.1111/jcpt.12382

Vitetta, L., Butcher, B., Dal Forno, S., Vitetta, G., Nikov, T., Hall, S., \& Steels, E. (2020). A Double-Blind Randomized Placebo-Controlled Study Assessing the Safety, Tolerability and Efficacy of a Herbal Medicine Containing Pycnogenol Combined with Papain and Aloe vera in the Prevention and Management of Pre-Diabetes. Medicines, 7(4), 22. https://doi.org/10.3390/medicines 7040022

Wautier, M. P., Guillausseau, P. J., \& Wautier, J. L. (2017). Activation of the receptor for advanced glycation end products and 
consequences on health. Diabetes and Metabolic Syndrome: Clinical Research and Reviews, 11(4), 305-309.

https://doi.org/10.1016/j.dsx.2016. 09.009

Yagi, A., Hegazy, S., Kabbash, A., \& Wahab, E. A. El. (2009). Possible hypoglycemic effect of Aloe vera L. high molecular weight fractions on type 2 diabetic patients. Saudi Pharmaceutical Journal, 17(3), 209-215.

https://doi.org/10.1016/j.jsps.2009 .08 .007

Zhang, Y., Liu, W., Liu, D., Zhao, T., \& Tian, H. (2016). Efficacy of aloe vera supplementation on prediabetes and early non-treated diabetic patients: A systematic review and meta-analysis of randomized controlled trials. Nutrients, $8(7)$. https://doi.org/10.3390/nu807038 8 